\title{
Rutin Isolated from Chrozophora tinctoria Enhances Bone Cell Proliferation and Ossification Markers
}

\author{
Ashraf B. Abdel-Naim (D, , ${ }^{1,2}$ Abdullah A. Alghamdi, ${ }^{3}$ Mardi M. Algandaby, ${ }^{1,4}$ \\ Fahad A. Al-Abbasi, ${ }^{1,3}$ Ahmed M. Al-Abd, ${ }^{2,5}$ Basma G. Eid ${ }^{1},{ }^{2}$ Hossam M. Abdallah, 6 ,7 \\ and Ali M. El-Halawany ${ }^{7}$ \\ ${ }^{1}$ Medicinal Plants Research Group, Deanship of Scientific Research, King Abdulaziz University, Jeddah, Saudi Arabia \\ ${ }^{2}$ Department of Pharmacology and Toxicology, Faculty of Pharmacy, King Abdulaziz University, Jeddah, Saudi Arabia \\ ${ }^{3}$ Department of Biochemistry, Faculty of Science, King Abdulaziz University, Jeddah, Saudi Arabia \\ ${ }^{4}$ Department of Biological Sciences, Faculty of Science, King Abdulaziz University, Jeddah, Saudi Arabia \\ ${ }^{5}$ Pharmacology Department, Medical Division, National Research Centre, Giza, Egypt \\ ${ }^{6}$ Department of Natural Products, Faculty of Pharmacy, King Abdulaziz University, Jeddah, Saudi Arabia \\ ${ }^{7}$ Department of Pharmacognosy, Faculty of Pharmacy, Cairo University, Cairo, Egypt
}

Correspondence should be addressed to Ashraf B. Abdel-Naim; abnaim@yahoo.com

Received 12 October 2017; Revised 25 November 2017; Accepted 17 December 2017; Published 13 February 2018

Academic Editor: Lotfi Aleya

Copyright (C) 2018 Ashraf B. Abdel-Naim et al. This is an open access article distributed under the Creative Commons Attribution License, which permits unrestricted use, distribution, and reproduction in any medium, provided the original work is properly cited.

\begin{abstract}
Osteoporosis is a chronic disease in which the skeleton loses a weighty proportion of its mineralized mass and mechanical pliability. Currently available antiosteoporotic agents suffer adverse effects that include elevated risk of thrombosis and cancer. Phytochemicals may constitute a safer and effective option. In the current work, six flavonoids were obtained from Chrozophora tinctoria and identified as amentoflavone (1), apigenin-7-O- $\beta$-D-glucopyranoside (2), apigenin-7-O-6" coumaroyl- $\beta$-D-glucopyranoside (3), acacetin-7-O- $\beta$-D- $[\alpha$-L-rhamnosyl $(1 \rightarrow 6)] 3^{\prime \prime}-E$ - $p$-coumaroyl glucopyranoside (4), apigenin$7-O$ - $\left(6^{\prime \prime}\right.$-Z-p-coumaroyl)- $\beta$-D-glucopyranoside (5), and rutin (6). An extensive review of the literature as well as NMR and mass spectral techniques was employed in order to elucidate the compound structures. Proliferation was enhanced in MCF7, MG-63, and SAOS-2 cells after exposure to subcytotoxic levels of the tested flavonoids. Rutin was chosen for subsequent studies in SAOS-2 cells. Rutin was not found to cause any alteration in the index of proliferation of these cells, when examining the cell cycle distribution by DNA flowcytometric analysis. Rutin was, however, found to increase osteocyte and osteoblast-related gene expression and lower the expression of RUNX suppressor and osteoclast genes. When examining the influence of rutin on vitamin D levels and the activity of alkaline phosphatase enzyme, it was found to enhance both, while decreasing acid phosphatase which is a marker of osteoporosis. Thus, rutin enhances proliferation and ossification markers in bone cells.
\end{abstract}

\section{Introduction}

Osteoporosis is a chronic disease in which the skeleton loses a weighty proportion of its mineralized mass and mechanical pliability [1]. It occurs when bone resorption surpasses bone formation, causing an imbalance [2]. As a result, the bones tend to become more fragile and more susceptible to fractures [3]. Studies have shown that $50 \%$ of women and $20 \%$ of men are likely to have a fracture resulting from osteoporosis during their lifetime [4]. Such fractures impose a heavy health and economic burden worldwide $[5,6]$. The risk of developing osteoporosis has been shown to be directly linked to diet. Studies have reported that people eating healthy diets with a high fruit and vegetable content tend to have lower bone resorption than their counterparts eating poor diets rich in processed foods [7]. Pharmacological management of osteoporosis involves the use of bisphosphonates and estrogen replacement therapy. However, these 
medicines suffer adverse effects that may range from gastric irritation to increased thromboembolic and cancer risks [8-10]. Therefore, it is imperative that we look for safer and effective alternatives. In this regard, medicinal herbs and plant-derived molecules have gained wide acceptance by the public and scientific communities [11].

Flavonoids, which are widely found in fruit and vegetables, are bioactive polyphenols with anti-inflammatory and antioxidant properties. Bone health has been associated with the intake of flavonoids. Intake of flavonoids increases bone mass density (BMD) in the neck and spine and decreases bone resorption in perimenopausal women [12]. Moreover, catechins and flavanones were found to associate with markers of bone resorption negatively. At the hip and spine, anthocyanins were found to be strongly linked with BMD [13]. It has been postulated that the reduction of low-grade inflammation and oxidative stress by flavonoids is the hallmark of protecting bone loss. In addition, flavonoids are thought to promote the upregulation of signaling pathways that increase the activity of osteoblasts [14].

Chrozophora tinctoria (L.) A. Juss. has several other names including turnsole, Dyer's croton or giradol. It is an annual plant that belongs to the Euphorbiaceae family [15]. Experimentally, it exhibited antioxidant and wound healing effects $[16,17]$. It exerts pronounced anti-inflammatory activities which involve inhibition of TNF- $\alpha, \mathrm{PGE}_{2}$, IL- $1 \beta$, and IL- 6 [18]. Phytochemically, this plant is rich in biflavones, such as amentoflavone in addition to many flavonoids including apigenin, rutin, quercetin, and acacetin [15, 18-20]. The current work aimed at isolating, identifying, and assessing the activity of major flavonoids isolated from C. tinctoria on markers of ossification and proliferation of bone cells.

\section{Materials and Methods}

2.1. Material for Phytochemical Studies. UV IKON $940 \mathrm{spec}-$ trophotometer was used to measure UV spectra. A Bruker Apex III Fourier-transform ion cyclotron resonance (FTICR) mass spectrometer (Bruker Daltonics, Billerica, USA) including an Infinity ${ }^{\mathrm{TM}}$ cell and a 7.0 Tesla superconducting magnet (Bruker, Karlsruhe, Germany) was used to perform mass spectrometric studies. A Bruker DRX-600 MHz Ultrashield spectrometer (Bruker BioSpin, Billerica, MA, USA) was utilized to measure NMR spectra. Chromatographic separation of the active compounds was performed on Silica gel 60 (70-230 mesh, Merck, Darmstadt, Germany), Silica gel $100 \mathrm{C}_{18}$-Reversed phase (0.04-0.063 mm, Merck, Darmstadt, Germany), and Sephadex LH-20 (Pharmacia Fine Chemicals Inc., Uppsala, Sweden). Monitoring of the isolation process was carried out on TLC plates with Silica gel $60 \mathrm{~F}_{254}$ (Merck, Darmstadt, Germany).

2.2. Plants Utilized in the Study. Chrozophora tinctoria (L.) A. Juss., Euphorbiaceae aerial parts were obtained from AlHadda road, Kingdom of Saudi Arabia (April 2015). These specimens were authenticated by Dr. Emad Al-Sharif, Department of Biology, King Abdulaziz University, Saudi Arabia. A specimen (reg. number CO-1080) was retained in the herbarium of the Department of Natural Products and Alternative Medicine, Saudi Arabia.

2.3. Phenolic Compound Extraction. The isolation process was performed as previously reported [18]. In brief, two kilograms of the aerial parts of $C$. tinctoria were dried and methanol was used as an extraction solvent till exhaustion to give a $150 \mathrm{~g}$ residue. The total extract was suspended in the least amount of water and extracted with chloroform leaving flavonoid-rich mother liquor that was separated using a Diaion HP-20 column starting with water up to $100 \%$ methanol to give three fractions (A-C). Fraction A was free from any phenolic compounds. Silica gel column chromatography was employed to separate fraction $\mathrm{B}$ $(50 \times 5 \mathrm{~cm}, 180 \mathrm{~g}) . \mathrm{CHCl}_{3}: \mathrm{MeOH}$ was employed with gradient elution resulting in three fractions, I, II, and III. The first fraction $(0.5 \mathrm{~g})$ was separated on CC Sephadex LH-20 using the eluent $\mathrm{MeOH}$ to give compound 1 (50 mg). The second fraction ( $1.5 \mathrm{~g})$ was subjected to chromatography with reversed phase Silica gel $100 \mathrm{C}_{18}$-column and $\mathrm{MeOH}: \mathrm{H}_{2} \mathrm{O}$, $3: 7$ as an eluent to give compound $2(40 \mathrm{mg})$. The third fraction ( $2 \mathrm{~g}$ ) was repeatedly fractionated on Sephadex LH20 using $\mathrm{MeOH}$ as an eluent; followed by $\mathrm{CC}$ on reversed phase Silica gel $100 \mathrm{C}_{18}$ using a system of $\mathrm{MeOH}$ : water, 3:7; and finally purification was performed on HPLC using a Zorbax SB-C18 column $(9.4 \times 250 \mathrm{~mm})$, flow rate $5 \mathrm{ml} / \mathrm{min}$ to give to compounds $3(20 \mathrm{mg}), 4$ (35 mg), and $5(45 \mathrm{mg})$. Fraction $\mathrm{C}$ was chromatographed on Sephadex LH-20 using $\mathrm{MeOH}$ as an eluent to give compound $6(20 \mathrm{mg})$.

2.4. Chemical Compounds and Media. Sulfarhodamine B (SRB), RNAse-A enzyme, $17 \beta$-hydroxyestradiol, and propidium iodide (PI) were obtained from Sigma-Aldrich (St. Louis, MO, USA). Cell culture materials such as DMEM media, fetal bovine serum (FBS), McCoy's-5A media, and MEM media were obtained from $\mathrm{Gibco}^{\mathrm{TM}}$, Thermo Fisher Scientific (Waltham, MA, USA). The chemicals utilized in this study were of the highest available analytical grade.

2.5. Cell Culture. The cell lines used in this study were human breast adenocarcinoma cells (MCF-7 cell line), in addition to human osteosarcoma cell lines (SAOS-2 and MG-63). These estrogen-dependent cell lines were purchased from the VACCERA (Giza, Egypt). The cells were kept in DMEM, MEM, and McCoy's-5A media, respectively. Streptomycin $(100 \mu \mathrm{g} / \mathrm{ml})$, penicillin (100 units/ml), and heat-inactivated FBS $(10 \% \mathrm{v} / \mathrm{v})$ were added to the media. Cells were kept in at $37^{\circ} \mathrm{C}$ and in humid conditions $5 \%(v / v) \mathrm{CO}_{2}$ atmosphere.

2.6. Assessment of Cytotoxicity. The cytotoxic effects of the compounds obtained from $C$. tincturia were examined in MCF-7, SAOS-2, and MG-63 cells using SRB assay as described in the previous work [21]. Trypsin-EDTA $(0.25 \%$ $w / v)$ was utilized to briefly detach exponentially growing cells. Subsequently, cells were transferred to 96-well plates $\left(10^{3}\right.$ cells per well). The test compounds were applied for $72 \mathrm{~h}$ to the cells. The cells were then fixed using TCA $(10 \%$ $w / v)$ at $4^{\circ} \mathrm{C}$ for $1 \mathrm{~h}$. Subsequently, the cells were washed three times and SRB solution $(0.4 \% w / v)$ was added in a dark room 
for $10 \mathrm{~min}$ after which glacial acetic acid $(1 \% v / v)$ was applied for a final wash. Cells were dried and the SRB-stained cells were dissolved by Tris- $\mathrm{HCl}(0.1 \mathrm{M})$. A microplate reader was utilized to record the color intensity at $540 \mathrm{~nm}$.

2.7. Determination of Doubling Time Using the Proliferation Assay. SRB assay was employed to calculate the doubling time (as a measure for the proliferative effect) of MCF-7, SAOS-2, and MG-63 cells in the presence of and absence of incubation with the compounds isolated from C. tincturia. A subcytotoxic concentration $(1 \mu \mathrm{M})$ of the flavonoids obtained from $C$. tincturia was shortly applied to cells growing exponentially in media free of phenol red for $96 \mathrm{~h}$. SRB solution was used to stain cells in order to carry out their quantification and to calculate doubling time using the best fit linear regression analysis curve [22].

2.8. Cell Cycle Distribution Study. In order to determine the effects of rutin on the cell cycle distribution, $1 \mu \mathrm{M}$ rutin was applied to SAOS-2 cells for $48 \mathrm{~h}$ and a comparison was made relative to $0.1 \mu \mathrm{M}$ estradiol. Trypsin was used to detach and collect the cells, after which PBS was added to wash the cells twice at $4^{\circ} \mathrm{C}$. The cells were then resuspended in PBS $(0.5 \mathrm{ml})$. Ethanol (ice-cold $70 \% v / v)(2 \mathrm{ml})$ was applied while shaking. This was followed by an incubation of the cells for $1 \mathrm{~h}$ at $4^{\circ} \mathrm{C}$ to allow fixation to occur. Cells were then analyzed, washed, and resuspended in PBS $(1 \mathrm{ml})$ containing $50 \mu \mathrm{g} / \mathrm{ml}$ of RNAase-A and $10 \mu \mathrm{g} / \mathrm{ml}$ of PI. The cells were kept in the dark $\left(20^{\circ} \mathrm{C}\right)$ for 20 minutes and the DNA contents were determined. After being passed into an ACEA Novocyte ${ }^{\mathrm{TM}}$ flow cytometer (ACEA Biosciences Inc., San Diego, CA, USA), the cells were analyzed using a FL2 signal detector $(\lambda$ ex/em $535 / 617 \mathrm{~nm}$ ) for PI positive events. Phases of the cell cycle were determined by ACEA NovoExpress ${ }^{\mathrm{TM}}$ software (ACEA Biosciences Inc., San Diego, CA, USA) for every sample $(12,000$ events per sample) subsequent to defining cell fragment-free fluorescent gate. Cells in the supra- $\mathrm{G}_{2} / \mathrm{M}$ phase were identified using ungated events. Total cells in $S$ - and $G_{2} / M$ phases were divided by cells in $G_{0} / G_{1}$ phases in order to calculate the proliferation index.

2.9. Gene Array Studies. Expression of osteogenic- and osteolytic-related genes was studied by exposing the cells $\left(1 \times 10^{6}\right)$ to either $1 \mu \mathrm{M}$ rutin or $0.1 \mu \mathrm{M}$ estradiol for $48 \mathrm{~h}$. The latter served as a positive control. RNeasy Mini Kit ${ }^{\circledR}$ (Qiagen Inc., Valencia, CA, USA) was used for RNA extraction. cDNA was obtained by reverse transcription with a cDNA Reverse Transcription Kit (Applied Biosystems, Foster City, CA). PCR was performed in real time on the cDNA via GeneQuery ${ }^{\mathrm{TM}}$ Human Osteogenic Differentiation qPCR Array (Science Cell Research Laboratories Inc., Carlsbad, CA, USA) according to the manufacturer's instructions [23]; $\beta$-actin was selected as the housekeeping gene. The formula: $2^{-\Delta \Delta \mathrm{Cq}}$ was employed to detect the normalized change in the gene expression of the studied genes after treatment with rutin and estradiol.

2.10. Osteoporosis Marker Assessment. The effects of rutin on ossification markers in the SAOS-2 cell line were determined by the application of $1 \mu \mathrm{M}$ rutin or $0.1 \mu \mathrm{M}$ estradiol to $1 \times 10^{6}$ cells for $48 \mathrm{~h}$. The latter served as a positive control. After collecting the media, assays of vitamin $\mathrm{D}$, alkaline phosphatase (ALP), osteocalcin (OC), and acid phosphatase (ACP) were performed. A direct HTS-ready colorimetric kit (Abcam, Cambridge, UK) was used to determine ALP as well as tartrate-resistant ACP [24]. Uscan ${ }^{\circledR}$ immunoassay ELISA Kit (Life Science Inc., Wuhan, China) was utilized to detect osteocalcin [25]. Human Total 25-OH Vitamin D IVD ELISA Kit (R\&D Systems, Inc., Minneapolis, MN, USA) was used to detect vitamin $\mathrm{D}$ in its active form.

2.11. Statistical Analysis. Data are presented as mean \pm SD. Analysis of variance (ANOVA) and Tukey's post hoc test were used to calculate statistical significance by SPSS ${ }^{\circledR}$ for Windows, version 17.0.0. $p<0.05$ was regarded as being statistically significant.

\section{Results and Discussion}

There is an immense need for the development of novel drugs to treat osteoporosis which are devoid of potentially life-threatening side effects, namely, stroke and carcinogenesis $[8,26]$. We have previously found that the phenolic compound paradol, isolated from Aframomum meleguea seeds, showed proliferative effects in bone cells [27]. Flavonoids have been shown by numerous studies to prevent bone loss $[12,28-31]$. Since C. tinctoria is rich in flavonoids as apigenin, rutin, quercetin, and acacetin $[18,20]$, we examined the effects of these compounds on proliferation and ossification markers. Mechanistically, the plant has been shown to impede several pathologic processes leading to osteoporosis as oxidative stress and inflammation [18]. Our study focused on isolating and determining the activity of its flavonoids on bone cell proliferation and ossification markers. Six metabolites were isolated from the C. tinctoria after phytochemical analysis (Figure 1). Cochromatography with authentic samples was used to identify these compounds, in addition to referring to spectral data from the literature. The identified compounds were amentoflavone (1) [32, 33], apigenin-7-O$\beta$-D-glucopyranoside (2) [34], apigenin-7-O- $6^{\prime \prime}-E$ - $p$-coumaroyl- $\beta$-D-glucopyranoside (3) [35], acacetin-7-O- $\beta$-D- $[\alpha-\mathrm{L}-$ rhamnosyl $(1 \rightarrow 6)] 3^{\prime \prime}-E$-p-coumaroyl glucopyranoside $(4)$ [18], apigenin-7-O-(6 $6^{\prime \prime}-Z$ - $p$-coumaroyl $)-\beta$-D-glucopyranoside (5) [18], and rutin (6) [34].

The cytotoxicity of these compounds was studied using the $\mathrm{SRB}$ viability assay in various estrogenic cell lines, namely, MCF-7, SAOS-2, and MG-63 cells. We have previously used these cell lines to study the effects of paradol on A. meleguea seeds, where we noted an accelerated proliferation [27]. In the present study, when looking at the effects on MCF-7 cells, the compounds showed a maximum of $20 \%$ alteration in the viability of cells, after being applied to the compounds for $72 \mathrm{~h}$ in $10 \mu \mathrm{M}$ concentrations. Exposing the cells to a higher concentration $(100 \mu \mathrm{M})$ of amentoflavone for $72 \mathrm{~h}$ (1) lead to a $78.8 \%$ viability of the control untreated cells (Table 1). As in the MCF-7 cells, exposure of SAOS- 2 cells to the compounds at $10 \mu \mathrm{M}$ concentration for $72 \mathrm{~h}$ showed a maximum of $20 \%$ change in viability. However, increasing the concentration of the compounds $1,3,5$, 
<smiles>O=c1cc(-c2ccc(O)c(-c3c(O)cc(O)c4c(=O)cc(-c5ccc(O)cc5)oc34)c2)oc2cc(O)cc(O)c12</smiles><smiles>O=c1cc(-c2ccc(O)cc2)oc2cc(OC3OCC(O)C(O)C(O)C3O)cc(O)c12</smiles>

(2)<smiles>O=C(/C=C/c1ccc(O)cc1)OCC(OC(O)C(O)C(O)O)C(O)Oc1cc(O)c2c(=O)cc(-c3ccc(O)cc3)oc2c1</smiles><smiles></smiles>

(4)

(3)<smiles></smiles>

(5)<smiles></smiles>

(6)

Figure 1: Isolated compounds from Chrozophora tincturia.

and 6 to $100 \mu \mathrm{M}$ induced a viability drop down to $70.1 \%$, $66.2 \%, 77.1 \%$, and $76.2 \%$ of the untreated control cells, respectively (Table 1 ). Interestingly, MG-63 cells were the most affected by the compounds under investigation. The addition of the compounds under investigation $(0.1 \mu \mathrm{M})$ to MG-63 cells for $72 \mathrm{~h}$ had no more than a $20 \%$ change in the viability of the cells. However, exposure to $1 \mu \mathrm{M}$ of 1 and 5 reduced cell viability to $74.9 \%$ and $78.1 \%$ of the control cells, respectively. The addition of a greater concentration $(10 \mu \mathrm{M})$ of all flavonoids under investigation induced 20 $40 \%$ killing effect at $72 \mathrm{~h}$ of exposure. Further exposure to $100 \mu \mathrm{M}$ of all compounds under investigation dropped cell viability of MG-63 cells to $40-70 \%$ of the control untreated cells (Table 1). 
TABLE 1: Cytotoxicity assessment of compounds isolated from C. tincturia.

\begin{tabular}{|c|c|c|c|c|c|c|}
\hline \multirow{2}{*}{\multicolumn{2}{|c|}{ Cpd }} & \multicolumn{5}{|c|}{ Percent viability } \\
\hline & & $0.01 \mu \mathrm{M}$ & $0.1 \mu \mathrm{M}$ & $1 \mu \mathrm{M}$ & $10 \mu \mathrm{M}$ & $100 \mu \mathrm{M}$ \\
\hline \multirow{6}{*}{ MCF-7 } & 1 & $95.8 \pm 1.6$ & $91.5 \pm 3.4$ & $88.6 \pm 3.3$ & $84.8^{*} \pm 1.6$ & $78.8^{*} \pm 0.3$ \\
\hline & 2 & $99.4 \pm 1.2$ & $94.8 \pm 3.3$ & $91.1 \pm 3.2$ & $90.3 \pm 2.4$ & $85.9^{*} \pm 1.6$ \\
\hline & 3 & $99.1 \pm 0.3$ & $95.1 \pm 3.4$ & $94.0 \pm 2.5$ & $92.8 \pm 1.7$ & $90.5^{*} \pm 0.3$ \\
\hline & 4 & $99.8 \pm 0.5$ & $96.0 \pm 0.5$ & $94.5 \pm 3.1$ & $91.1 \pm 2.4$ & $87.9^{*} \pm 0.6$ \\
\hline & 5 & $98.3 \pm 1.2$ & $91.8 \pm 2.7$ & $88.9 \pm 2.8$ & $86.9^{*} \pm 1.7$ & $80.2^{*} \pm 1.2$ \\
\hline & 6 & $97.5 \pm 1.5$ & $93.2 \pm 3.8$ & $90.4 \pm 3.4$ & $88.2^{*} \pm 2.1$ & $80.3^{*} \pm 1.7$ \\
\hline \multirow{6}{*}{ SAOS-2 } & 1 & $98.9 \pm 0.8$ & $95.1 \pm 0.9$ & $92.1 \pm 0.9$ & $80.4^{*} \pm 0.9$ & $70.1^{*} \pm 0.2$ \\
\hline & 2 & $99.2 \pm 0.6$ & $97.4 \pm 2.0$ & $94.5 \pm 1.3$ & $92.8 \pm 1.6$ & $89.3^{*} \pm 1.5$ \\
\hline & 3 & $97.4 \pm 1.0$ & $96.8 \pm 0.9$ & $91.9 \pm 1.7$ & $84.7 \pm 3.4$ & $66.2^{*} \pm 1.2$ \\
\hline & 4 & $98.4 \pm 0.7$ & $95.8 \pm 0.8$ & $92.7 \pm 0.4$ & $90.1 \pm 0.9$ & $84.7^{*} \pm 1.0$ \\
\hline & 5 & $97.0 \pm 1.5$ & $92.9 \pm 0.8$ & $90.9 \pm 0.5$ & $85.4^{*} \pm 0.5$ & $77.1^{*} \pm 0.5$ \\
\hline & 6 & $96.6 \pm 0.8$ & $93.6 \pm 0.7$ & $92.6 \pm 1.9$ & $88.5^{*} \pm 1.2$ & $76.2^{*} \pm 0.9$ \\
\hline \multirow{6}{*}{ MG-63 } & 1 & $88.2 \pm 0.1$ & $82.3 \pm 1.2$ & $74.9^{*} \pm 2.0$ & $61.3^{*} \pm 0.4$ & $40.4^{*} \pm 0.5$ \\
\hline & 2 & $95.9 \pm 2.7$ & $88.8 \pm 2.0$ & $81.1^{*} \pm 0.3$ & $74.9^{*} \pm 1.4$ & $70.9^{*} \pm 0.6$ \\
\hline & 3 & $96.7 \pm 2.0$ & $92.2 \pm 1.6$ & $87.4 \pm 1.2$ & $80.8^{*} \pm 0.2$ & $64.3^{*} \pm 1.1$ \\
\hline & 4 & $98.1 \pm 0.4$ & $93.2 \pm 1.3$ & $87.2^{*} \pm 0.8$ & $79.8^{*} \pm 2.0$ & $60.2^{*} \pm 1.7$ \\
\hline & 5 & $93.1 \pm 0.9$ & $83.4 \pm 1.2$ & $78.1^{*} \pm 0.8$ & $67.7^{*} \pm 1.1$ & $54.7^{*} \pm 2.1$ \\
\hline & 6 & $91.1 \pm 0.7$ & $86.2 \pm 0.8$ & $82.2 \pm 1.2$ & $73.0^{*} \pm 1.2$ & $63.4^{*} \pm 0.4$ \\
\hline
\end{tabular}

Cells were treated with test compounds for $72 \mathrm{~h}$ and viability was determined using SRB assay. Data are expressed as mean \pm SD; $n=6$. ${ }^{*}$ Significantly different from control untreated cells $(p<0.05)$.

It has been previously reported that several flavonoids and related phytochemicals interact with estrogen receptors $[36,37]$. The influence of a subcytotoxic concentration $(1 \mu \mathrm{M})$ from all compounds under investigation on doubling times of MCF-7, SAOS-2, and MG-63 cells was tested. A concentration of $0.1 \mu \mathrm{M} \mathrm{E}_{2}$ served as a positive control. Compounds 1,3 , and 6 caused a significant lowering of the doubling times of MCF-7 cells from $16.6 \pm 1.4 \mathrm{~h}$ to 9.3 $\pm 0.2 \mathrm{~h}, 8.6 \pm 0.4 \mathrm{~h}$, and $7.2 \pm 0.5 \mathrm{~h}$, respectively. The addition of $\mathrm{E}_{2}$ to MCF-7 cells resulted in a lowering of the doubling time to $8.5 \pm 0.4 \mathrm{~h}$ (Table 2). When studying the cell lines derived from bone osteosarcoma, compounds $1,3,4,5$, and 6 caused a decrease in the doubling time of SAOS- 2 cells from $49.3 \pm 4.1 \mathrm{~h}$ to $26.6 \pm 1.4 \mathrm{~h}, 14.7 \pm 0.7 \mathrm{~h}, 29.0 \pm 2.9 \mathrm{~h}$, $29.4 \pm 3.5 \mathrm{~h}$, and $15.7 \pm 0.2 \mathrm{~h}$, respectively. In SAOS- 2 cells, it was noted that $\mathrm{E}_{2}$ decreased the doubling time to 20.1 $\pm 1.2 \mathrm{~h}$ (Table 2). In addition, compounds $1,3,5$, and 6 lowered the MG-63 cells doubling time from $36.8 \pm 2.2 \mathrm{~h}$ to 20.9 $\pm 0.3 \mathrm{~h}, 21.0 \pm 0.3 \mathrm{~h}, 23.5 \pm 1.1 \mathrm{~h}$, and $20.8 \pm 0.5 \mathrm{~h}$, respectively, in comparison to $23.1 \pm 0.1 \mathrm{~h}$ by $\mathrm{E}_{2}$ (Table 2). It is worth mentioning that some flavonoids might be equipotent or ever more potent than $\mathrm{E}_{2}$ which might be attributed to the higher concentrations used (more than 10-fold). When comparing all tested flavonoids, rutin (6) showed promising proliferative properties with minimal expected mutagenic influence. This is in line with reports by Hyun et al. regarding its osteoclast activating properties [38]. Additionally, the selection of SAOS-2 cells for future studies was based upon their low viability drop when treated with the flavonoids being studied.

In this study, the flavonoids obtained from C. tinctoria displayed clear proliferative effects in all the three studied cell
TABle 2: Proliferative effects of compounds isolated from $C$. tincturia: doubling time assessment.

\begin{tabular}{lccc}
\hline & MCF-7 & SAOS2 & MG-63 \\
\hline Control & $16.6 \pm 1.4$ & $49.3 \pm 4.1$ & $36.8 \pm 2.2$ \\
1 & $9.3^{*} \pm 0.2$ & $26.3^{*} \pm 1.4$ & $20.9^{*} \pm 0.3$ \\
2 & $14.8+1.7$ & $35.7 \pm 3.4$ & $27.5 \pm 2.1$ \\
3 & $8.6^{*} \pm 0.4$ & $14.7^{*} \pm 0.7$ & $21.0^{*} \pm 0.3$ \\
4 & $11.8 \pm 3.6$ & $29.0^{*} \pm 2.9$ & $25.8^{*} \pm 3.5$ \\
5 & $13.4 \pm 3.2$ & $29.4^{*} \pm 3.5$ & $23.5^{*} \pm 1.1$ \\
6 & $7.2^{*} \pm 0.5$ & $15.7^{*} \pm 0.2$ & $20.8^{*} \pm 0.5$ \\
$\mathrm{E}_{2}$ & $8.5^{*} \pm 0.4$ & $20.1^{*} \pm 1.2$ & $23.1^{*} \pm 0.1$ \\
\hline
\end{tabular}

Cells were treated with test compounds $(1 \mu \mathrm{M})$ for up to $96 \mathrm{~h}$ and viability was determined using SRB assay. Doubling times were calculated and compared to control untreated cells and $\mathrm{E}_{2}(0.1 \mu \mathrm{M})$ treated cells (positive control). Data are expressed as mean $\pm \mathrm{SD} ; n=6$. ${ }^{*}$ Significantly different from the corresponding untreated cells; $p<0.05$.

lines. Although several studies have reported that estrogen along with various estrogen metabolites possesses proliferative properties, this was limited by the fact that they cause mutagenicity $[22,39]$. Therefore, it was of importance to record the impact of rutin on the distribution of the phases of cell cycle in relation to the progression of the cell cycle flow cytometry to determine DNA content. Treatment of SAOS-2 cells with $1 \mu \mathrm{M}$ rutin for $48 \mathrm{~h}$ was carried out. Exposing the cells to $0.1 \mu \mathrm{M} \mathrm{E}_{2}$ served as a positive control. Interestingly, rutin produced a significant increase of cells in $G_{0} / G_{1}$ from $55.2 \pm 2.4 \%$ to $62.6 \pm 1.1 \%$ with a reciprocal decrease for cells in S-phase from $30.7 \pm 2.9 \%$ to $22.5 \pm 1.0 \% . \mathrm{G}_{2} / \mathrm{M}$ phase was 


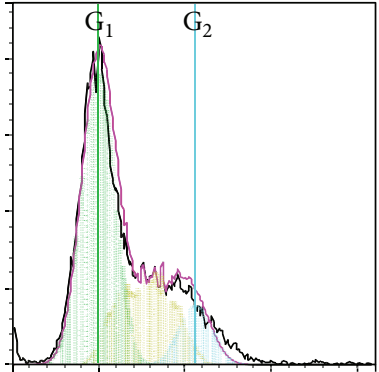

(b)

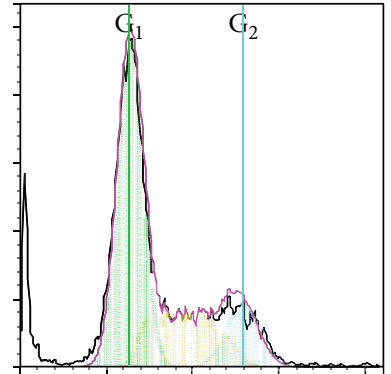

(a)

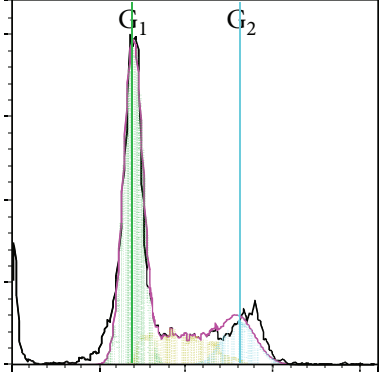

(c)

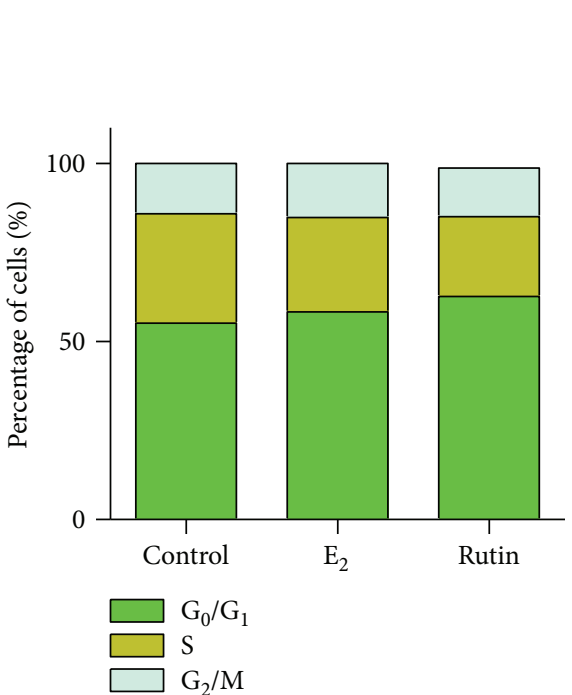

(d)

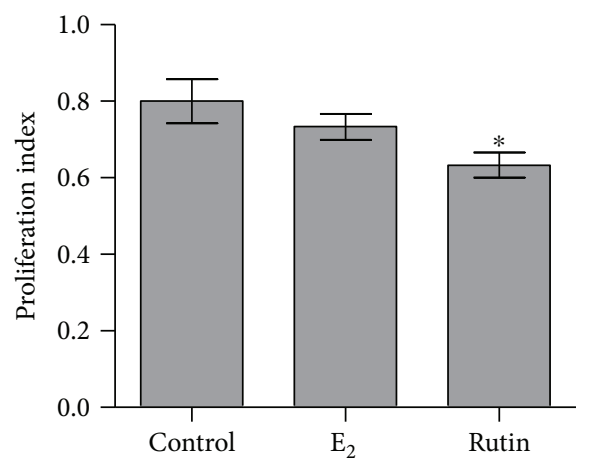

(e)

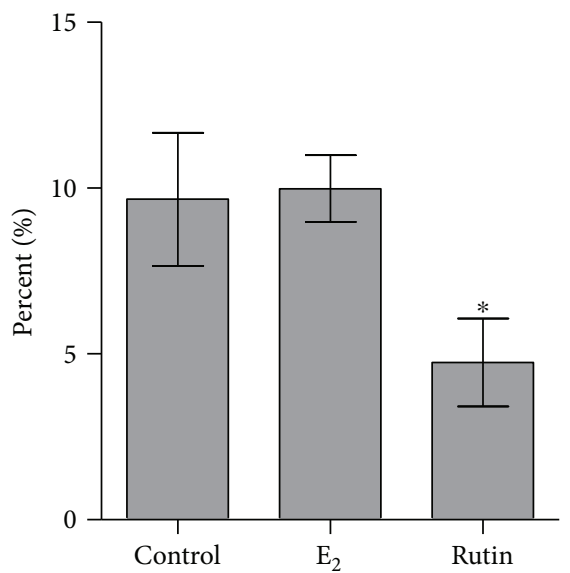

FIGURE 2: Effect of rutin on the cell cycle distribution of SAOS-2 cells. Cells were exposed to rutin $(1 \mu \mathrm{M})$ for $48 \mathrm{~h}$ (b) and compared to control untreated cells $(\mathrm{a})$ and $\mathrm{E}_{2^{-}}(0.1 \mu \mathrm{M})$ treated cells $(\mathrm{c})$. Cell cycle distribution was determined using DNA cytometry analysis and different cell phases were plotted (d) as percentage of total events. Proliferation index was calculated and plotted (e). Supra- $\mathrm{G}_{2} / \mathrm{M}$ cell population was plotted as percent of total events (f). Data are presented as mean \pm SD; $n=3$. *Significantly different from the control untreated cells; $p<0.05$.

not affected by treatment with rutin (Figures $2(\mathrm{a}), 2(\mathrm{c})$, and $2(\mathrm{~d}))$. However, $0.1 \mu \mathrm{M} \mathrm{E}_{2}$ produced a significant drop of cells in the S-phase $(30.7 \pm 2.9 \%$ to $26.5 \pm 0.9 \%)$. Treating SAOS- 2 cells with $\mathrm{E}_{2}$ caused no significant changes of cells in $G_{0} / G 1$ or S-phases (Figures 2(a), 2(b), and 2(d)). When studying the proliferating cell fraction balance in SAOS-2 cells, rutin significantly decreased the proliferation index; on the other hand, treatment with $\mathrm{E}_{2}$ did not alter their proliferation index (Figure 2(e)). In a previous study in our laboratory, paradol showed no influence on the proliferation index of SAOS-2 cells [27]. Our current data are in alignment with our studies on SAOS- 2 cells where $1 \mu \mathrm{M}$ rutin was found to decrease the doubling time. Yet, we tested the nature of the rutin proliferative effect in SAOS-2; accumulation of cells in the supra- $\mathrm{G}_{2}$ compartment (multiploidy phase) might indicate uncontrolled cell proliferation. Interestingly, after SAOS-2 exposure to rutin, cells in supra- $\mathrm{G}_{2}$ phase were much lower than control cells (Figure 2(f)). This indicates a punctuated cell division without cell accumulation in multiploidy phase [40]. This gains support by the known chemopreventive and anticarcinogenic properties of rutin [41-43].
Several studies have reported that targeting ossification is a more fruitful approach than targeting proliferation, when looking at developing new drug targets to treat osteoporosis. $[44,45]$. The effects of rutin on osteogenic marker gene expression were quantitatively studied using RT-PCR gene array battery kit that comprises various osteogenic gene families. These include osteocyte, osteoclast, and osteoblast activity markers, as well as RUNX suppressor genes. When studying the osteocyte activity markers (BGN, FGF23, PDPN, HYOU1, and SOST), rutin and $\mathrm{E}_{2}$ caused an increase in expression of all the tested osteocyte activity gene markers by 1.9 - to 2.9 -folds and 2.7 - to 3.5 -folds, respectively (Figure 3(a)). The role of osteocytes in calcium and phosphate homeostasis has been previously reported. Osteocytes cloned with BGN caused acceleration of osteoblast differentiation in vitro and an increase in the area of lamellar bone-like matrices in vivo [46]. Phosphate levels are known to decline due to the presence of the FGF23 protein [47]. Dividing osteocytes are known to express PDPN, which is regarded as a marker of activity [48]. They also secrete SOST causing a negative effect on the formation of bones [49]. Also, rutin 


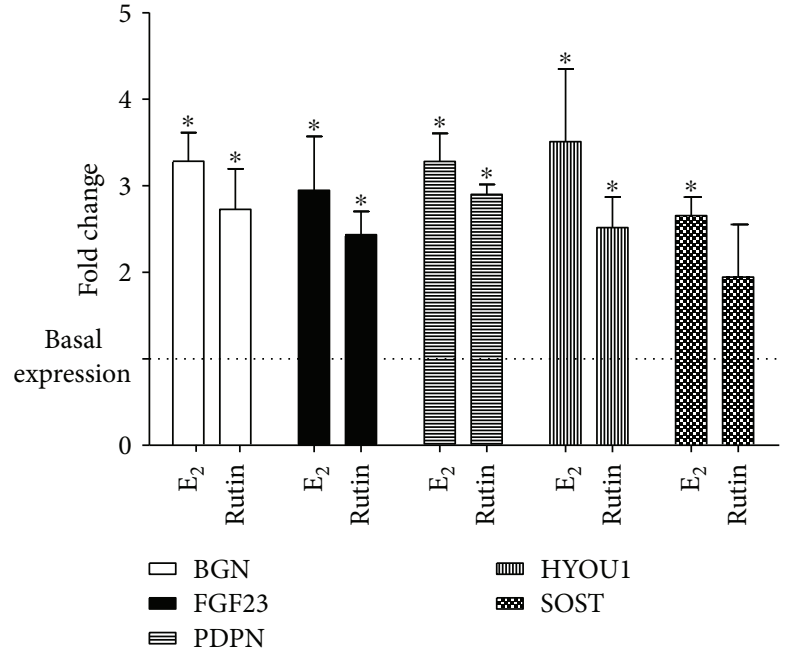

(a) Osteocyte markers

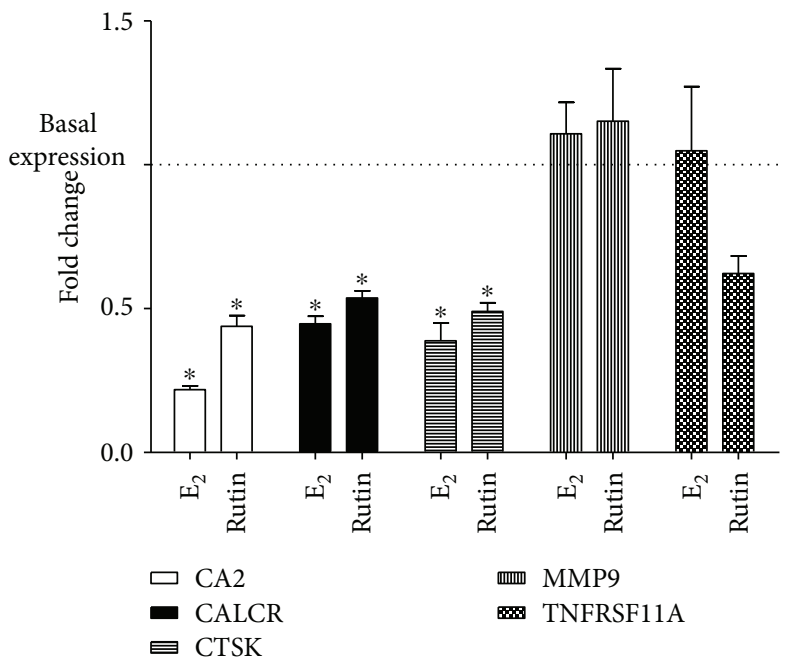

(c) Osteoclast markers

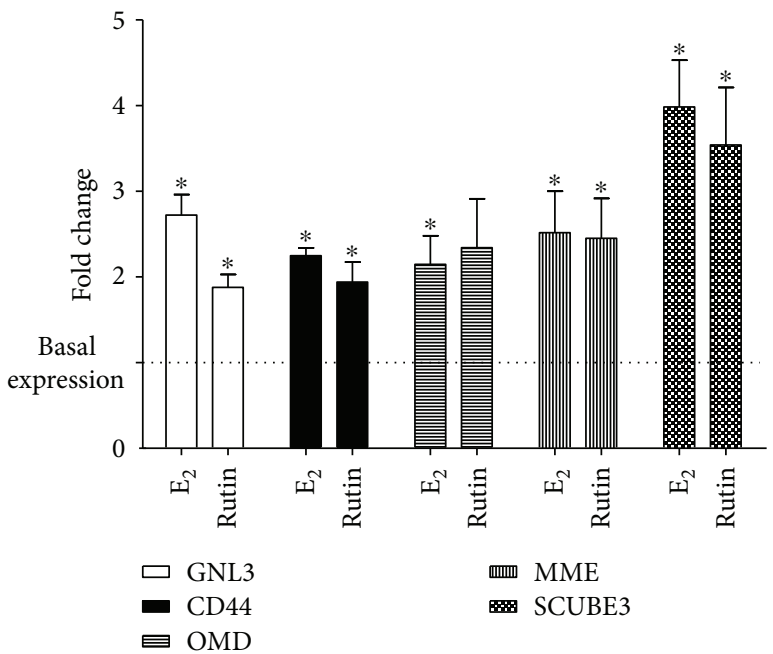

(b) Osteoblast markers

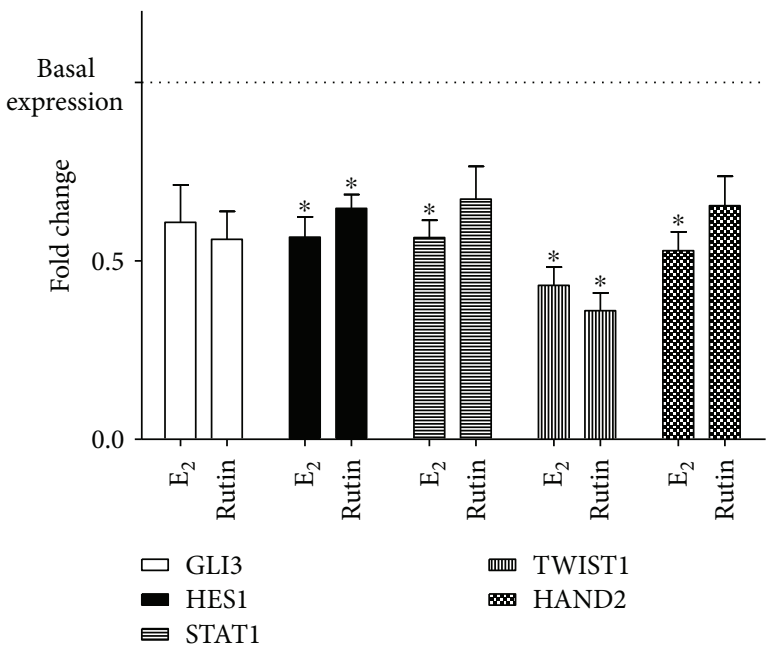

(d) RUNX suppressors

FIGURE 3: Effect of rutin on mRNA expression of some ossification related genes in SAOS-2 cell line. Cells were incubated with rutin ( $1 \mu \mathrm{M})$ or $\mathrm{E}_{2}(0.1 \mu \mathrm{M})$ for $48 \mathrm{~h}$. Total RNA was extracted and subjected to RT-PCR. Data were normalized to $\beta$-actin; fold changes were calculated and expressed as mean $\pm \mathrm{SD} ; n=3$. * Significantly different from the control untreated cells; $p<0.05$.

increased the expression level of GNL3,CD44, MME, and SCUBE3 osteoblast activity markers, by $1.8 \pm 0.2-, 1.9 \pm 0.3-$, $2.5 \pm 0.7$-, and $3.5 \pm 0.9$-folds, respectively. $O M D$ expression after rutin treatment was not changed. The five tested gene markers of osteoblast activity were augmented by 2.1- to 4.0-folds after the application of $\mathrm{E}_{2}$ (Figure 3(b)). Compared to our previous work on paradol [27], rutin significantly increased HYOU1 but not SOST. Further, rutin could significantly enhance expression of the osteoblast marker CD44 while paradol failed to exert a similar effect. With respect to osteoclast activity markers, both rutin and $\mathrm{E}_{2}$ downregulated CA2, CALCR, and CTSK expression to 0.4- to 0.5 -folds and 0.2 - to 0.4 -folds, respectively. The expression of MMP9 and TNFRSF11A genes was unaltered after treatment with either rutin or $\mathrm{E}_{2}$ (Figure 3(c)). These findings confirm the potential favorable effects of rutin. This is further supported by studies in the bone marrow that showed rutin inhibits osteoclastogenesis [50]. When studying the RUNX suppressor gene family
(GLB, HES1, STAT1, TWIST1, and HAND2), rutin downregulated the expression of HES1and TWIST1 mRNA to 0.7 \pm 0.1 - and $0.4 \pm 0.07$-folds of the control cells, respectively. On the other hand, $\mathrm{E}_{2}$ was found to suppress HES1, STAT1, TWIST1, and HAND2 gene expression to 0.4- to 0.6-folds of control (Figure 3(d)). Studies have reported that RUNX regulates RANKL leading to the maturation and differentiation of osteoblasts [51]. The lowered expression of HES1and TWIST1 (RUNX suppressors) by rutin supports its osteogenic effects. All these data are in alignment with our previous publication on paradol [27]. However, rutin showed superior activities with regard to suppressing CALCR expression.

In the present study, we determined the effects of treating SAOS- 2 cells with $1 \mu \mathrm{M}$ rutin for $48 \mathrm{~h}$ on the levels of four essential osteoporosis-related markers. The results were compared with treatment of the cells with $0.1 \mu \mathrm{M} \mathrm{E}_{2}$ as a positive control. Rutin produced a significant increase in the activity/concentrations of all ossification markers, ALP 


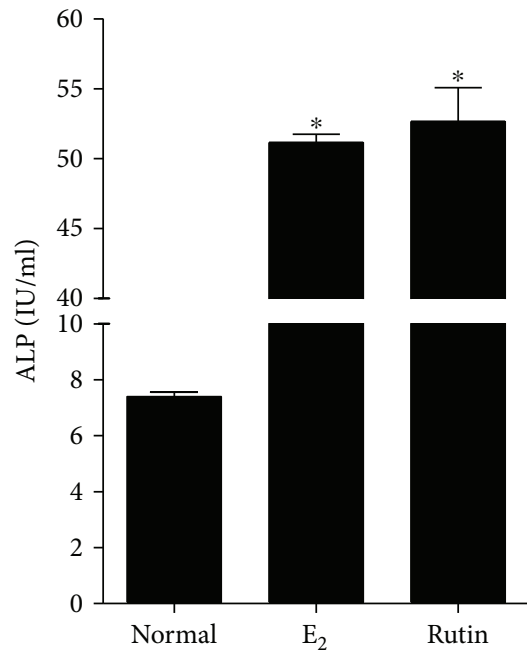

(a)

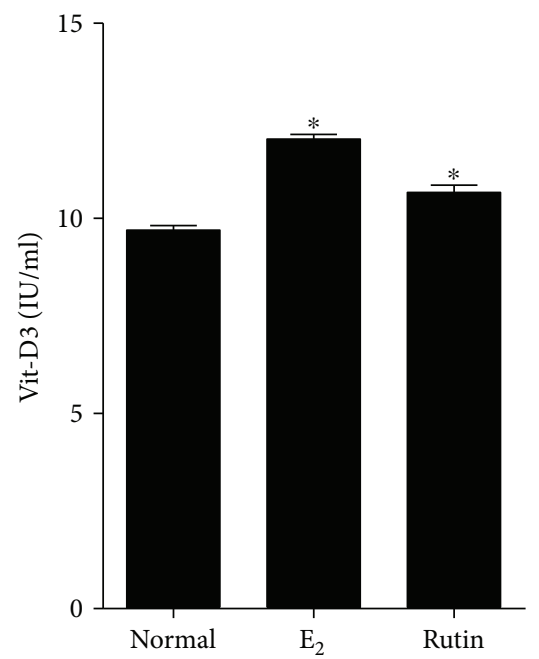

(c)

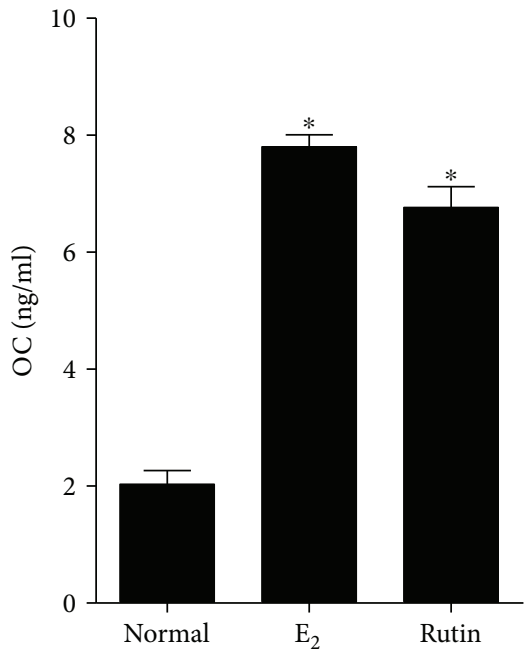

(b)

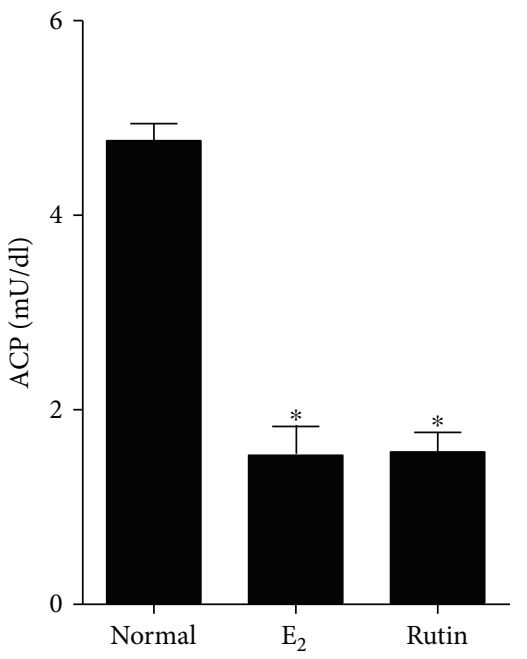

(d)

FIGURE 4: Biochemical assessment for antiosteoporosis effect of rutin in vitro. SAOS-2 cells were treated with rutin $(1 \mu \mathrm{M})$ and $\mathrm{E}_{2}(0.1 \mu \mathrm{M})$ for $48 \mathrm{~h}$ and compared to the control untreated cells. Biochemical assessment of osteoporosis was evaluated by measuring alkaline phosphatase (a), osteocalcin (b), vitamin D3 (c), and acid phosphatase (d). Data are presented as mean \pm SD; $n=3$. * Significantly different from the control untreated cells; $p<0.05$.

enzyme, OCN hormone, and active Vit-D3 concentration, by 7.1-, 3.4-, and 1.1-folds, respectively. Similarly, $\mathrm{E}_{2}$ increased the activity/concentrations of ALP enzyme, OCN hormone, and active Vit-D3 concentration, by 6.9-, 3.9-, and 1.2-folds, respectively (Figures $4(\mathrm{a})-4(\mathrm{c})$ ). On the other hand, rutin produced a statistically significant drop in ACP enzyme activity (bone resorption marker) from $4.7 \pm 0.4 \mathrm{IU} / \mathrm{ml}$ to $1.6 \pm 0.4 \mathrm{IU} / \mathrm{ml}$ compared to $1.5 \pm 0.4 \mathrm{IU} / \mathrm{ml}$ for $\mathrm{E}_{2}$-treated cells (Figure 4(d)). The biochemical markers chosen in this study are well documented in the literature as reliable markers having antiosteoporotic properties. [52]. In conclusion, the analysis of $C$. tinctoria extract led to the isolation of various flavonoids showing antiosteoporosis influence. Rutin was especially promising as it showed ossification in bone cells as well as possessing punctuate proliferative activity with minimal influence to cell cycle distribution.
In other words, rutin might be further studied as a potential antiosteoprotic agent with minimal expected mutagenic effects.

\section{Conflicts of Interest}

The authors declare no conflicts of interest.

\section{Acknowledgments}

This project was funded by the Deanship of Scientific Research (DSR), King Abdulaziz University, Jeddah, Saudi Arabia, under Grant no. (1-166-35 RG). The authors, therefore, acknowledge with thanks DSR for technical and financial support. 


\section{References}

[1] R. M. Martin and P. H. S. Correa, "Bone quality and osteoporosis therapy," Arquivos Brasileiros de Endocrinologia \& Metabologia, vol. 54, no. 2, pp. 186-199, 2010.

[2] K. Akesson, "New approaches to pharmacological treatment of osteoporosis," Bulletin of the World Health Organization, vol. 81, no. 9, pp. 657-664, 2003.

[3] K. E. Ensrud and C. J. Crandall, "Osteoporosis," Annals of Internal Medicine, vol. 167, no. 3, pp. ITC17-ITC32, 2017.

[4] T. P. van Staa, E. M. Dennison, H. G. Leufkens, and C. Cooper, "Epidemiology of fractures in England and Wales," Bone, vol. 29, no. 6, pp. 517-522, 2001.

[5] W. D. Leslie, C. J. Metge, M. Azimaee et al., "Direct costs of fractures in Canada and trends 1996-2006: a populationbased cost-of-illness analysis," Journal of Bone and Mineral Research, vol. 26, no. 10, pp. 2419-2429, 2011.

[6] J. P. van den Bergh, T. A. van Geel, and P. P. Geusens, "Osteoporosis, frailty and fracture: implications for case finding and therapy," Nature Reviews Rheumatology, vol. 8, no. 3, pp. 163$172,2012$.

[7] A. C. Hardcastle, L. Aucott, W. D. Fraser, D. M. Reid, and H. M. Macdonald, "Dietary patterns, bone resorption and bone mineral density in early post-menopausal Scottish women," European Journal of Clinical Nutrition, vol. 65, no. 3, pp. 378-385, 2011.

[8] L. M. Brass, "Estrogens and stroke: use of oral contraceptives and postmenopausal use of estrogen: current recommendations," Current Treatment Options in Neurology, vol. 6, no. 6, pp. 459-467, 2004.

[9] W. Strampel, R. Emkey, and R. Civitelli, "Safety considerations with bisphosphonates for the treatment of osteoporosis," Drug Safety, vol. 30, no. 9, pp. 755-763, 2007.

[10] D. A. Yardley, "Pharmacologic management of bone-related complications and bone metastases in postmenopausal women with hormone receptor-positive breast cancer," Breast Cancer: Targets and Therapy, vol. 8, pp. 73-82, 2016.

[11] L. Wu, Z. Ling, X. Feng, C. Mao, and Z. Xu, "Herb medicines against osteoporosis: active compounds \& relevant biological mechanisms," Current Topics in Medicinal Chemistry, vol. 17, no. 15, pp. 1670-1691, 2017.

[12] A. C. Hardcastle, L. Aucott, D. M. Reid, and H. M. Macdonald, "Associations between dietary flavonoid intakes and bone health in a Scottish population," Journal of Bone and Mineral Research, vol. 26, no. 5, pp. 941-947, 2011.

[13] A. Welch, A. MacGregor, A. Jennings, S. Fairweather-Tait, T. Spector, and A. Cassidy, "Habitual flavonoid intakes are positively associated with bone mineral density in women," Journal of Bone and Mineral Research, vol. 27, no. 9, pp. 1872-1878, 2012.

[14] A. A. Welch and A. C. Hardcastle, "The effects of flavonoids on bone," Current Osteoporosis Reports, vol. 12, no. 2, pp. 205210, 2014.

[15] R. Gibbs, Chemotaxonomy of Flowering Plants, McGillQueen's University Press, Montreal, 1974.

[16] F. Oke-Altuntas, S. Ipekcioglu, A. Sahin Yaglioglu, L. Behcet, and I. Demirtas, "Phytochemical analysis, antiproliferative and antioxidant activities of Chrozophora tinctoria: a natural dye plant," Pharmaceutical Biology, vol. 55, no. 1, pp. 966973, 2017.
[17] H. Maurya, M. Semwal, and S. K. Dubey, "Pharmacological evaluation of Chrozophora tinctoria as wound healing potential in diabetic rat's model," BioMed Research International, vol. 2016, Article ID 7475124, 7 pages, 2016.

[18] H. M. Abdallah, F. M. Almowallad, A. Esmat, I. A. Shehata, and E. A. Abdel-Sattar, "Anti-inflammatory activity of flavonoids from Chrozophora tinctoria," Phytochemistry Letters, vol. 13, pp. 74-80, 2015.

[19] E. Hecker, "Cocarcinogenic principles from the seed oil of Croton tiglium and from other Euphorbiaceae," Cancer Research, vol. 28, no. 11, pp. 2338-2349, 1968.

[20] U. W. Hawas, "Antioxidant activity of brocchlin carboxylic acid and its methyl ester from Chrozophora brocchiana," Natural Product Research, vol. 21, no. 7, pp. 632-640, 2007.

[21] P. Skehan, R. Storeng, D. Scudiero et al., "New colorimetric cytotoxicity assay for anticancer-drug screening," JNCI Journal of the National Cancer Institute, vol. 82, no. 13, pp. 1107-1112, 1990.

[22] H. A. Mosli, M. F. Tolba, A. M. Al-Abd, and A. B. Abdel-Naim, "Catechol estrogens induce proliferation and malignant transformation in prostate epithelial cells," Toxicology Letters, vol. 220, no. 3, pp. 247-258, 2013.

[23] J. Vandesompele, K. De Preter, F. Pattyn et al., “Accurate normalization of real-time quantitative RT-PCR data by geometric averaging of multiple internal control genes," Genome Biology, vol. 3, article RESEARCH0034, 2002.

[24] W. Gerhardt, M. L. Nielsen, O. V. Nielsen, J. S. Olsen, and B. E. Statland, "Clinical evaluation of routine measurement of liver and bone alkaline phosphatases in human serum: differential inhibition by L-phenylalanine and carbamide (urea) on the LKB 8600 reaction rate analyzer," Clinica Chimica Acta, vol. 53, no. 3, pp. 291-297, 1974.

[25] J. Y. Fu and D. Muller, "Simple, rapid enzyme-linked immunosorbent assay (ELISA) for the determination of rat osteocalcin," Calcified Tissue International, vol. 64, no. 3, pp. 229-233, 1999.

[26] P. D. Papapetrou, "Bisphosphonate-associated adverse events," Hormones, vol. 8, no. 2, pp. 96-110.

[27] A. B. Abdel-Naim, A. A. Alghamdi, M. M. Algandaby et al., "Phenolics isolated from Aframomum meleguta enhance proliferation and ossification markers in bone cells," Molecules, vol. 22, no. 9, 2017.

[28] I. Fernandes, R. Pérez-Gregorio, S. Soares, N. Mateus, and V. de Freitas, "Wine flavonoids in health and disease prevention," Molecules, vol. 22, no. 4, p. 292, 2017.

[29] C.-L. Shen and M.-C. Chyu, "Tea flavonoids for bone health: from animals to humans," Journal of Investigative Medicine, vol. 64, no. 7, pp. 1151-1157, 2016.

[30] Y. Gao, F. Yang, H. Xi, W. Li, P. Zhen, and K. Chen, "Effects of icariin total flavonoids capsule on bone mineral density and bone histomorphometry in growing rats," Zhejiang Da Xue Xue Bao. Yi Xue Ban, vol. 45, no. 6, pp. 581-586, 2016.

[31] Y.-L. Huang, C.-C. Shen, Y.-C. Shen, W.-F. Chiou, and C.-C. Chen, "Anti-inflammatory and Antiosteoporosis flavonoids from the rhizomes of Helminthostachys zeylanica," Journal of Natural Products, vol. 80, no. 2, pp. 246-253, 2017.

[32] C. A. Carbonezi, L. Hamerski, A. A. L. Gunatilaka et al., "Bioactive flavone dimers from Ouratea multiflora (Ochnaceae)," Revista Brasileira de Farmacognosia, vol. 17, no. 3, pp. 319324, 2007. 
[33] Y.-M. Zhang, R. Zhan, Y.-G. Chen, and Z.-X. Huang, "Two new flavones from the twigs and leaves of Cephalotaxus lanceolata," Phytochemistry Letters, vol. 9, pp. 82-85, 2014.

[34] M. Shabana, M. El-Sherei, M. Moussa, A. Sleem, and H. Abdallah, "Investigation of phenolic constituents of Carduncellus eriocephalus Boiss. Var. albiflora Gauba and their biological activities," Natural Product Communications, vol. 2, pp. 823-828, 2007.

[35] M. Plioukas, A. Termentzi, C. Gabrieli, M. Zervou, P. Kefalas, and E. Kokkalou, "Novel acylflavones from Sideritis syriaca ssp. syriaca," Food Chemistry, vol. 123, no. 4, pp. 1136-1141, 2010.

[36] S. Lecomte, M. Lelong, G. Bourgine, T. Efstathiou, C. Saligaut, and F. Pakdel, "Assessment of the potential activity of major dietary compounds as selective estrogen receptor modulators in two distinct cell models for proliferation and differentiation," Toxicology and Applied Pharmacology, vol. 325, pp. 61-70, 2017.

[37] X. Wang, N. Zheng, J. Dong, X. Wang, L. Liu, and J. Huang, "Estrogen receptor- $\alpha 36$ is involved in icaritin induced growth inhibition of triple-negative breast cancer cells," The Journal of Steroid Biochemistry and Molecular Biology, vol. 171, pp. 318-327, 2017.

[38] H. Hyun, H. Park, J. Jeong et al., "Effects of watercress containing rutin and rutin alone on the proliferation and osteogenic differentiation of human osteoblast-like MG-63 cells," The Korean Journal of Physiology \& Pharmacology, vol. 18, no. 4, pp. 347-352, 2014.

[39] A. M. Soto and C. Sonnenschein, "The role of estrogens on the proliferation of human breast tumor cells (MCF-7)," Journal of Steroid Biochemistry, vol. 23, no. 1, pp. 87-94, 1985.

[40] J. M. Mitchison and B. L. A. Carter, "Chapter 11 cell cycle analysis," Methods in Cell Biology, vol. 11, pp. 201-219, 1975.

[41] M. G. Hertog, P. C. Hollman, M. B. Katan, and D. Kromhout, "Intake of potentially anticarcinogenic flavonoids and their determinants in adults in The Netherlands," Nutrition and Cancer, vol. 20, no. 1, pp. 21-29, 1993.

[42] C. Chaumontet, M. Suschetet, E. Honikman-Leban et al., "Lack of tumor-promoting effects of flavonoids: studies on rat liver preneoplastic foci and on in vivo and in vitro gap junctional intercellular communication," Nutrition and Cancer, vol. 26, no. 3, pp. 251-263, 1996.

[43] S. Sharma, A. Ali, J. Ali, J. K. Sahni, and S. Baboota, "Rutin: therapeutic potential and recent advances in drug delivery," Expert Opinion on Investigational Drugs, vol. 22, no. 8, pp. 1063-1079, 2013.

[44] J. A. Kanis and C. C. Glüer, "An update on the diagnosis and assessment of osteoporosis with densitometry," Osteoporosis International, vol. 11, no. 3, pp. 192-202, 2000.

[45] T. D. Rachner, S. Khosla, and L. C. Hofbauer, "Osteoporosis: now and the future," The Lancet, vol. 377, no. 9773, pp. 1276-1287, 2011.

[46] D. Parisuthiman, Y. Mochida, W. R. Duarte, and M. Yamauchi, "Biglycan modulates osteoblast differentiation and matrix mineralization," Journal of Bone and Mineral Research, vol. 20, no. 10, pp. 1878-1886, 2005.

[47] R. Sapir-Koren and G. Livshits, "Osteocyte control of bone remodeling: is sclerostin a key molecular coordinator of the balanced bone resorption-formation cycles?," Osteoporosis International, vol. 25, no. 12, pp. 2685-2700, 2014.
[48] D. Dayong Guo and L. F. Bonewald, "Advancing our understanding of osteocyte cell biology," Therapeutic Advances in Musculoskeletal Disease, vol. 1, no. 2, pp. 87-96, 2009.

[49] X. Li, M. S. Ominsky, Q.-T. Niu et al., "Targeted deletion of the sclerostin gene in mice results in increased bone formation and bone strength," Journal of Bone and Mineral Research, vol. 23, no. 6, pp. 860-869, 2008.

[50] C. M. Rassi, M. Lieberherr, G. Chaumaz, A. Pointillart, and G. Cournot, "Modulation of osteoclastogenesis in porcine bone marrow cultures by quercetin and rutin," Cell and Tissue Research, vol. 319, no. 3, pp. 383-393, 2005.

[51] T. Komori, "Roles of runx2 in skeletal development," Advances in Experimental Medicine and Biology, vol. 962, pp. 83-93, 2017.

[52] H. M. Abdallah, A. M. Al-Abd, G. F. Asaad, A. B. Abdel-Naim, and A. M. El-halawany, "Isolation of antiosteoporotic compounds from seeds of Sophora japonica," PLoS One, vol. 9, no. 6 , article e98559, 2014. 


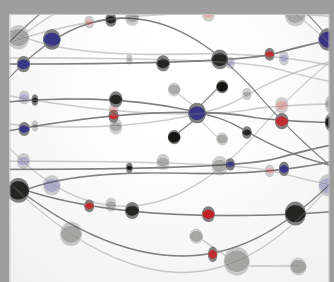

The Scientific World Journal
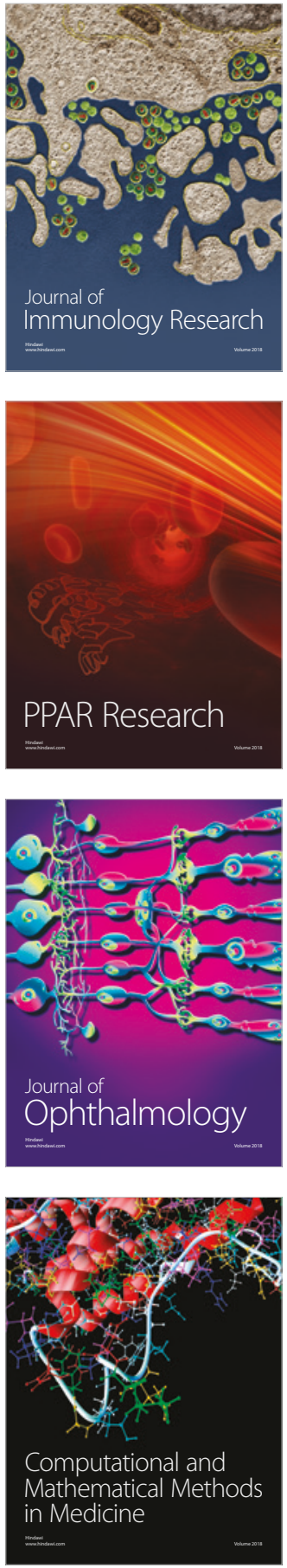

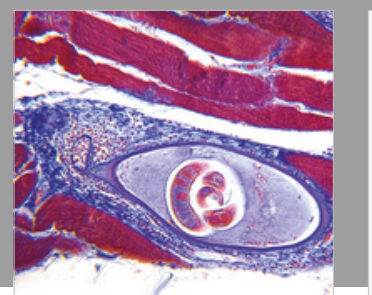

Gastroenterology Research and Practice

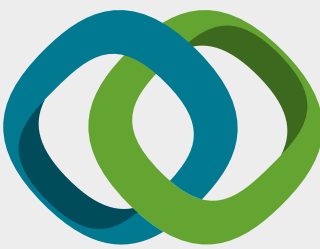

\section{Hindawi}

Submit your manuscripts at

www.hindawi.com
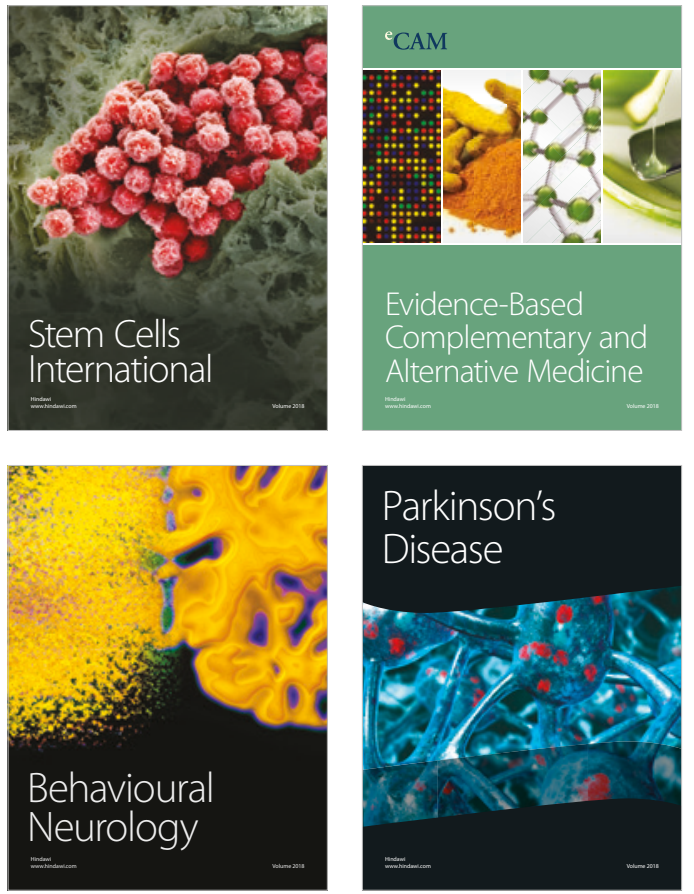

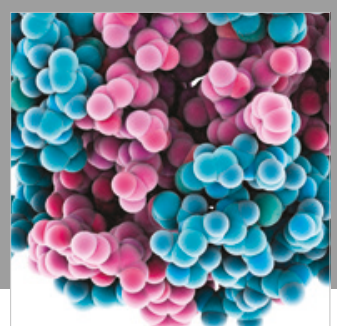

ournal of

Diabetes Research

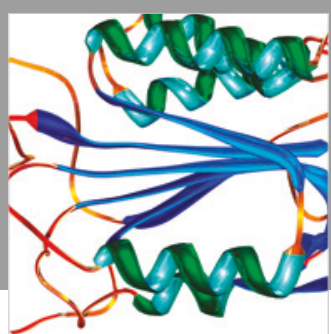

Disease Markers
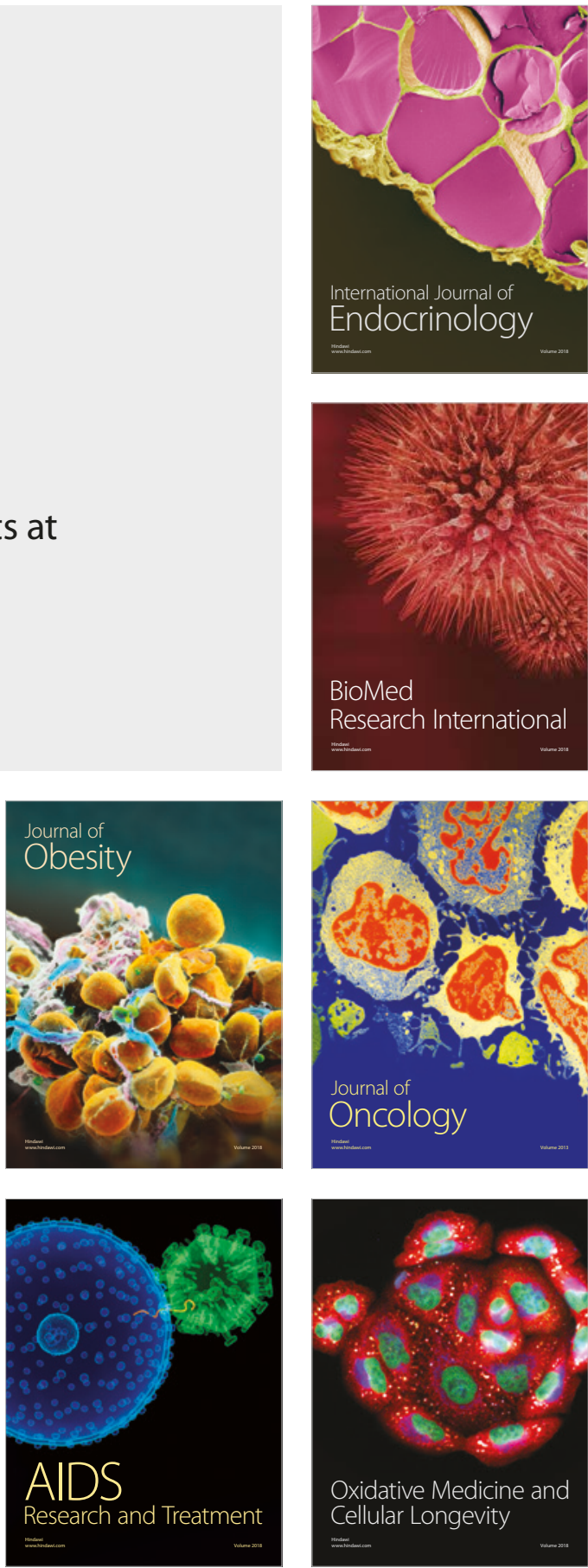